
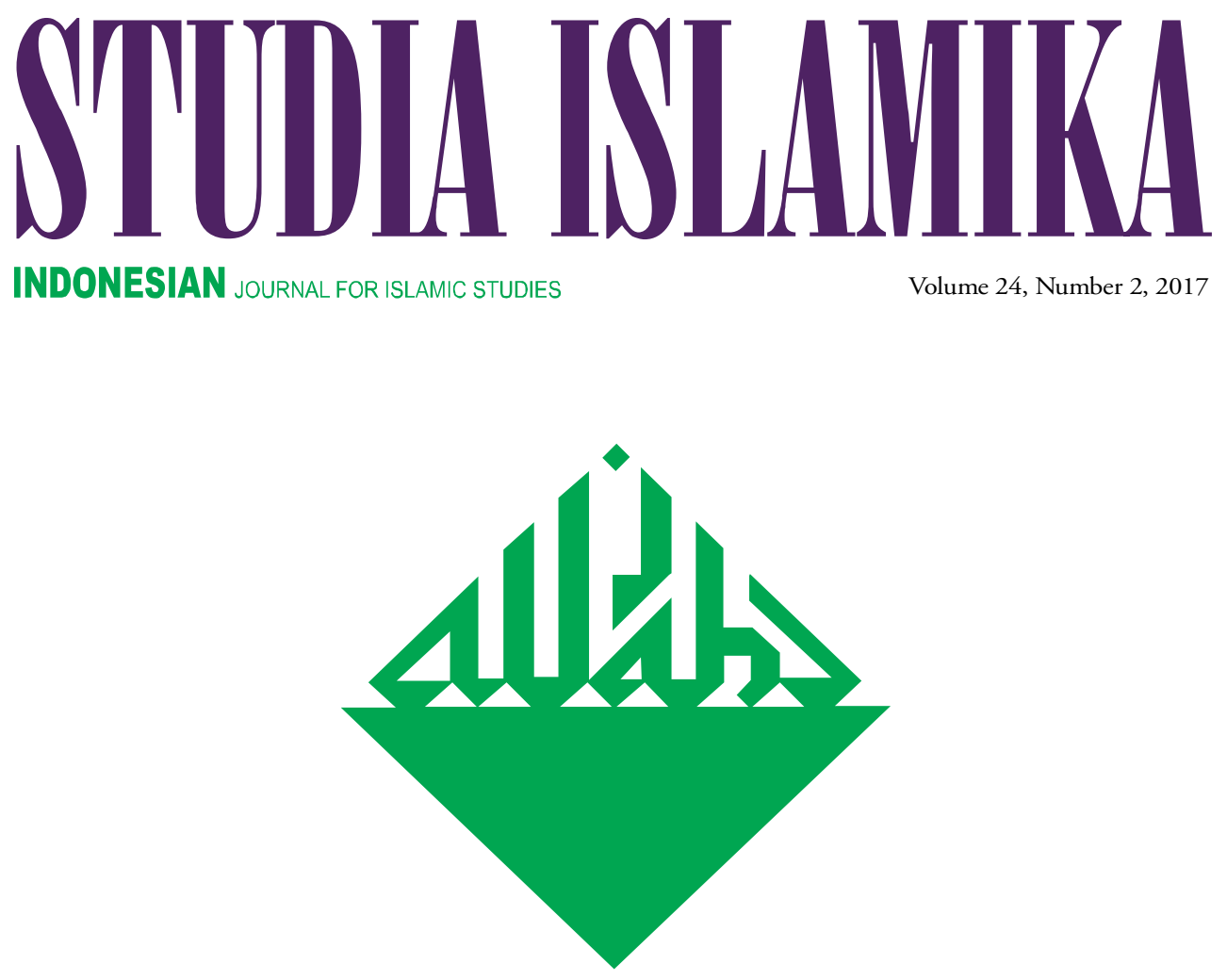

The Rise of the Khalwatiyah Sammān Sufi Order in South Sulawesi: Encountering the Local, ESCAPING THE GLOBAL

Achmad Ubaedillah

'RuMI' Networks OF AL-SinkīLī:

A Biography of BĀBA DĀWUd

Mehmet Özay

EXPLORING ISLAMIC SCHOOL LEADERSHIP

in a Challenging Southern Thailand Context

Raihani

Prolonged Elite Conflict and the Destruction of the Indonesian Islamic Union Party (PSII)

Valina Singka Subekti 
STIUDLA ISLAMIIIKA 



\title{
STIDIA ISLAIIIKA
}

Indonesian Journal for Islamic Studies

Vol. 24, no. 2, 2017

EDITOR-IN-CHIEF

Azyumardi Azra

MANAGING EDITOR

Oman Fathurahman

\section{EDITORS}

Saiful Mujani

Jamhari

Didin Syafruddin

Jajat Burhanudin

Fuad Jabali

Ali Munhanif

Saiful Umam

Ismatu Ropi

Dadi Darmadi

Jajang Jahroni

Din Wahid

INTERNATIONAL EDITORIAL BOARD

M. Quraish Shihab (Syarif Hidayatullah State Islamic University of Jakarta, INDONESIA)

Taufik Abdullah (Indonesian Institute of Sciences (LIPI), INDONESIA)

M.C. Ricklefs (Australian National University, AUSTRALIA)

Martin van Bruinessen (Utrecht University, NETHERLANDS)

John R. Bowen (Washington University, USA)

M. Kamal Hasan (International Islamic University, MALAYSIA)

Virginia M. Hooker (Australian National University, AUSTRALIA)

Edwin P. Wieringa (Universität zu Köln, GERMANY)

Robert W. Hefner (Boston University, USA)

Rémy Madinier (Centre national de la recherche scientifique (CNRS), FRANCE)

R. Michael Feener (National University of Singapore, SINGAPORE)

Michael F. Laffan (Princeton University, USA)

ASSISTANT TO THE EDITORS

Testriono

Muhammad Nida' Fadlan

Endi Aulia Garadian

ENGLISH LANGUAGE ADVISOR

Dick van der Meij

Daniel Peterson

\author{
ARABIC LANGUAGE ADVISOR \\ Tb. Ade Asnawi
}

COVER DESIGNER

S. Prinka 
STUDIA ISLAMIKA (ISSN 0215-0492; E-ISSN: 2355-6145) is an international journal published by the Center for the Study of Islam and Society (PPIM) Syarif Hidayatullah State Islamic University of Jakarta, INDONESIA. It specializes in Indonesian Islamic studies in particular, and Southeast Asian Islamic studies in general, and is intended to communicate original researches and current issues on the subject. This journal warmly welcomes contributions from scholars of related disciplines. All submitted papers are subject to double-blind review process.

STUDIA ISLAMIKA has been accredited by The Ministry of Education and Culture, Republic of Indonesia as an academic journal (SK Dirjen Dikti No. 56/DIKTI/Kep/2012).

STUDIA ISLAMIKA has become a CrossRef Member since year 2014. Therefore, all articles published by STUDIA ISLAMIKA will have unique Digital Object Identifier (DOI) number.

STUDIA ISLAMIKA is indexed in Scopus since 30 May 2015.

(C) Copyright Reserved

Editorial Office:

STUDIA ISLAMIKA, Gedung Pusat Pengkajian

Islam dan Masyarakat (PPIM) UIN Jakarta,

Jl. Kertamukti No. 5, Pisangan Barat, Cirendeu,

Ciputat 15419, Jakarta, Indonesia.

Phone: (62-21) 7423543, 7499272, Fax: (62-21) 7408633;

E-mail: studia.islamika@uinjkt.ac.id

Website: http://journal.uinjkt.ac.id/index.php/studia-islamika

Annual subscription rates from outside Indonesia, institution: US $\$ 75,00$ and the cost of a single copy is US\$ 25,00; individual: US\$ 50,00 and the cost of a single copy is US\$ 20,00. Rates do not include international postage and handling.

Please make all payment through bank transfer to: PPIM, Bank Mandiri KCP Tangerang Graha Karnos, Indonesia, account No. 101-00-0514550-1 (USD),

\section{Swift Code: bmriidja}

Harga berlangganan di Indonesia untuk satu tahun, lembaga: Rp. 150.000,-, harga satu edisi Rp. 50.000,-; individu: Rp. 100.000,-, harga satu edisi Rp. 40.000,-. Harga belum termasuk ongkos kirim.

Pembayaran melalui PPIM, Bank Mandiri KCP Tangerang Graha Karnos, No. Rek: 128-00-0105080-3 


\section{Table of Contents}

\section{Articles}

213 Achmad Ubaedillah

The Rise of the Khalwatiyah Sammān Sufi Order

in South Sulawesi: Encountering the Local,

Escaping the Global

247 Mehmet Özay

'Rumi' Networks of al-Sinkîlī:

A Biography of Bāba Dāwud

271 Raihani

Exploring Islamic School Leadership in a Challenging Southern Thailand Context

295 Valina Singka Subekti

Prolonged Elite Conflict and the Destruction of the Indonesian Islamic Union Party (PSII)

337 Mohammad Iskandar

Al-Ḥarakāt al-munāhaḍah li al-mashāyikh 
wa al-'ulamā' al-ḥumr fì Priangan:

al-Ittihād al-akhḍar 1920-1949 namūdhajan

\section{Book Review}

379 Endi Aulia Garadian

Membaca Populisme Islam Model Baru

\section{Document}

395 Dirga Maulana

The Exclusivism of Religion Teachers:

Intolerance and Radicalism in Indonesian Public Schools 
Mehmet Özay

'Rumi' Networks of al-Sinkīlī: A Biography of Bāba Dāwud

\begin{abstract}
This paper introduces Shaykh Dāwud ibn Ismāill ibn Mustafá Rūmì (also known as Bäba Dāwud or Mustafá al-Rūmī) who was an Islamic scholar believed to have lived in Aceh sometime between 1650 and 1750 to the larger Muslim world. Shaykh Dāwud ibn Ismāìl ibn Mustafá Rümi is important for three reasons: (a) he lived during the time of the Sultanate of Aceh Darussalam (16th - 17th centuries) and he was the leading student and religious caliph of 'Abd al-Ra'üf al-Sinkilì (Teungku Syiah Kuala), the well-known Acehnese religious scholar; (b) his Risālat masāil al-muhtadī li ikhwān al-muhtadī has been taught at Islamic institutions in Aceh and all around the Malay world; and (c) no scholarly works have yet been written about him, despite the striking fact that he and Teungku Syiah Kuala co-founded the Dayah Manyang Leupue educational institution, to which he subsequently remained affiliated.
\end{abstract}

Keywords: Bāba Dāwud, Rūmī, 'Abd al-Ra'ūf al-Sinkìlī, Aceh Darussalam Sultanate, Southeast Asia. 
Abstrak: Artikel ini membahas Shaykh Dāwud ibn Ismāìl ibn Mustafá Rūmī (juga dikenal dengan nama Bāba Dāwud atau Mustafá al-Rūmī), yang merupakan seorang ulama yang dipercaya hidup di Aceh sekitar tahun 1650 dan 1750, kepada khalayak Muslim yang lebih luas. Shaykh Dāwud ibn Ismāìl ibn Mustafá Rūmì dianggap penting karena tiga alasan: (a) dia hidup pada masa Kesultanan Aceh Darussalam (Abad 1617) dan sebagai murid utama serta mufti dari 'Abd al-Ra'üf al-Sinkìlī (Teungku Syiah Kuala), seorang ulama Aceh yang sangat terkenal; (b) karyanya, Risālat masāil al-muhtadī li ikhwān al-muhtadī, diajarkan di lembaga-lembaga keagamaan di Aceh dan dunia Melayu; dan (c) belum ada sarjana yang menulis tentang dia, terlepas dari fakta bahwa dia dan Teungku Syiah Kuala bersama-sama mendirikan Dayah Manyang Leupue yang kemudian menjadi afliasinya.

Kata kunci: Bāba Dāwud, Rūmī, 'Abd al-Ra'ūf al-Sinkīili, Kesultanan Aceh Darussalam, Asia Tenggara.

$$
\begin{aligned}
& \text { ملخص: هذا المقال سوف يقدم إلى العالم الإسلامي الأوسع الشيخ داود بن إسماعيل بن }
\end{aligned}
$$

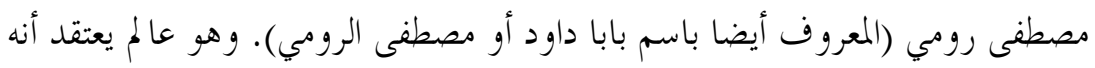

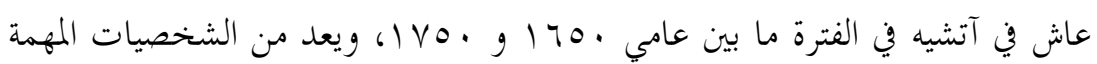

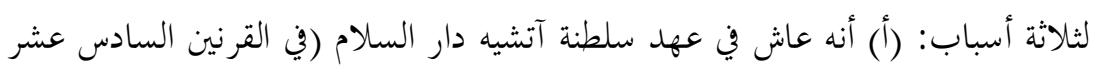

$$
\begin{aligned}
& \text { و السابع عشر) بصفته تلميذا رئيسيا ومفتيا لعبد الرؤوف السنكيلي (تينغكو شياه كو الا) } \\
& \text { عالم شهير من آتشيه؛ (ب) أن كتابه المعنون رسالة مسائل المهتدي لإخوان المهتدي يتم }
\end{aligned}
$$

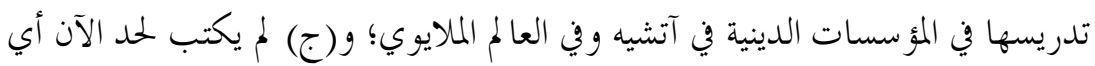

$$
\begin{aligned}
& \text { عمل علمي يتحدث عنه، بغض النظر عن الحقيقة التي تشير إلى أنه يشترك مع تينغكو شياه } \\
& \text { كوالا في تأسيس مؤسسة داياه مانيانغ ليو بو التعليمية التي أصبح فيما بعد ينتمي إليها. } \\
& \text { الكلمات المفتاحية: بابا داود، رومي، عبد الرؤوف السنكيلي، سلطنة آتشيه دار } \\
& \text { السلام، جنوب شرقي آسيا. }
\end{aligned}
$$


his article briefly discusses the life of Bāba Dāwud or Musțafá
al-Rūmī, the scholar of Turkish descent whose grave is located
in the provincial capital of Banda Aceh. It also attempts to answer several questions including, "Who was Bāba Dāwud or Musțafá al-Rūmī?", "How did he come to Aceh?" and "How did he obtain his education?" Much like in other pre-modern Southeast Asian societies, written culture was rare in Aceh and because of this, "biographic details of Malay writers of the pre-modern period are hard to come by" as other researchers on Malay manuscripts and literature have remarked (Hussainmiya 1989, 1). Thus, even though Aceh has produced many scholars, today few details are known from only a small number of them (Hurgronje 1906, 18; Johns 1976, 312, 1999, 109-10). The present undertaking should be seen as a modest contribution to the body of research on this least known scholarly individual who was virtually the only known scholar in Aceh of a Turkish background.

Existing documents on his life and scholarly personality, his works, and information about his offspring, are also presented below. Unfortunately, the relative lack of authentic primary sources is a serious obstacle. Nevertheless, the works he produced show that he seems to have been a figure of note among Acehnese scholarly circles.

At this stage, it is important to bear in mind the presence of Syiah Kuala, the renowned scholar who was Bāba Dāwud's guru starting from the second half of the $17^{\text {th }}$ century. This will allow us to clarify the era Bāba Dāwud was born in and when he shaped his intellectual identity. After Sultan Iskandār Thānīs death (r. 1637-1641), Aceh was ruled by female sultans for almost sixty years (1641-1699). During these years, Shaykh 'Abd al-Ra'ūf al-Sinkilī played a constructive role for the first sulțanah, Iskandār Thānīs widow, Șafiyat al-Dīn (1641-1675), and for her successors. al-Sinkilīi, who brought the Shațariyah Order to the Malay Archipelago (Azra 2004, 78; Daly 1994, 22, 30; Daudy 1997, 73; Hurgronje 1906, 18; Riddell 1984, 21; Rinkes 1996, 21), worked in the palace of Aceh as walìy al-Mulk (deputy sultān) (Azra 2004, 78) and he continued to produce scholarly works, including the first Malay interpretation of the Quran (Al-Attas 1969, 16) (according to Bayzavī's commentary) and a book on canon law entitled Mirat al-tulläb fì tashīl ma' rifat a h̦käm al-sharī'ah li al-Malik al-Wahhäb (Daly 1994, 2) ${ }^{1}$ both of which rank among his most important works. al-Sinkìlī also wrote about theology, canon law (fiqh), hadith, and Sufism (Amiruddin 2005, 13). 


\section{Bāba Dāwud}

Bāba Dāwud was probably born and raised some time after $1650 .^{2}$ His full name was Bāba Dāwud al-Jāwī ibn Ismā'īl al-Jāwī ibn Aghā Mustafá ibn Aghā Rūmī. Bāba Dāwud was also known as Musṭafá alRūmī (M. S. Abdullah 1999a, 15-16). The name tag al-jāwì indicates the possibility of his mother's Malay origin or of his birth in Indonesia (Azra 1998, 211; Laffan 2003, 351). ${ }^{3}$

There is no definite information about his birth and death dates. However, if we bear in mind that his teacher, 'Abd al-Ra'üf al-Sinkilī, lived from 1615 to 1693 and returned to Aceh in 1661 after his studies in Arabia, we may safely assume that he lived sometime between 1650 and $1750 .^{4}$

Bāba Dāwud is considered one of Syiah Kuala's leading students because of his role both in establishing Dayah Manyang Leupue and because he completed translations of important works (Azra 1992, 211). ${ }^{5}$ To date, authentic information about his identity has been found in two main works. The first is in the introduction to the Turjumān al-mustafìd ${ }^{6}$ which is a translation of Tafsìr al-jalälayn or of Tafsìr Baydawī by al-Sinkīlī and contributed to by Bāba Dāwud. The source says that Bāba Dāwud was a student of al-Sinkīli and that he had the following lineage: Bāba Dāwud ibn Ismāōil; Ismail ibn Aghā Musțafá; Aghā Musțafá ibn Aghā 'Alī al-Rūmī. ${ }^{8}$ The second work is entitled Manzar al-ajlá Martabat al-Alá and was written by Shaykh Faqīh Jalāl al-Dīn ibn Kamāl al-Dīn, one of Bāba Dāwud's students. It states that Bāba Dāwud was one of 'Abd al-Ra'ūf al-Sinkīlī students (M. S. Abdullah 1999a, 24-25). ${ }^{\text {? }}$

There are several opinions of the way Bāba Dāwud reached Aceh. According to Azyumardi Azra, he was one of the many soldiers the Ottomans deployed to support the Sultanate of Aceh to defend itself against the Portuguese (Azra 1992, 211, 2004, 258). But Wan Muhammad Shaghir Abdullah criticized this view and opined that Bāba Dāwud ar-Rūmī’s father was likely Ismā'îl al-Rūmī (d. 1631/1643), the shaykh of the Qādirī Order who was sent from Turkey to Aceh in this period (M. S. Abdullah 1999a, 24-25). ${ }^{10}$

Shaykh Dāwud ibn Ismāīil ibn Musțafá al-Rūmī is also known as Tunku Chik di Leupue (the Shaykh of Di Leupue), as it was a common practice to call religious scholars not by their own name but by the location where they had settled. In regard to this, Bāba Dāwud was 
called 'Tunku Chik di Leupue', because of his administrative service in the Dayah he had helped Syiah Kuala to establish in Banda Aceh's region called Leupeu. It is reputed that Shaykh 'Abd al-Ra' üf wanted him to manage Dayah Leupeu (Hasjmy 1977, 117; Ismuha 1971, 42; Mokhtar 2008, 56; Yakub 1980, 323). ${ }^{11}$

A close relation between 'Abd al-Ra'ūf and Bāba Dāwud was established by the customary handing over by the guru of a handwritten Quran to his student. In regard to this, a copy of the Quran, written by Shaykh 'Abd al-Ra' ūf in a special form of calligraphy was given to Bāba Dāwud. Upon the latter's death, it was transferred to Haji Yahya, the leader of Dayah Leupue and, apparently, handed down from generation to generation to his descendants. Until recently, it was in the hands of Teungku Abdulaziz Ujung in Peunauyong. Ali Hasjmy noted that he had once seen it (Hasjmy 1983, 218). It is believed that one of Syiah Kuala's descendants, by the name of Mahmud, owns a photocopy of this Quran. ${ }^{12}$

It is relevant to consider the word 'Rūmì' as it is part of Bāba Dāwud's full name. The word 'Rūmì' is commonly used in his name to refer to his Anatolian origins. Arabs and Persians usually used the word "Rūmï" to refer to the Byzantine Empire (Reid 2005, 69). ${ }^{13}$ After the Saljuq Turks conquered Anatolia and established Turkish sovereignty there, the name Rūmī was transferred onto them (Bates 1994, 257-59; Bressan 1997, 4; Flemming 1988, 125; Mersinli 1941, 160). ${ }^{14}$ When Sultan Mehmed the Conqueror defeated Constantinople, the name was used for the Ottoman Turks as well and continued to be the common designation for their empire even after it had become a major world power in the mid-fifteenth century. Therefore, Muslims who came to the Archipelago from this land were called "Rum" (İnalcık 1973, 73; Seljuq 1980, 301). ${ }^{15}$

It should also be remembered that in the Malay world the sovereignty of the Ottoman Sultans was expressed with the legendary words 'Raja Rum' (Andaya 1977, 129). One commonly comes across this usage in manuscripts and handwritten documents such as the Hikayat Marong Mahawangsa, the famous Kedah Annals (Marong Mahawangsa 2011, 11). There is also the term Benua Rom as found in the Hikayat Hang Tuah (K. Ahmad 1997, 501). ${ }^{16}$

Regarding the sultanate that was widely known as 'Rum/Greek Sultanate' in the Malay world, Azyumardi Azra had the following to say: 
"In Indonesia and the Malay world there is a special narrative about the Rum Sultanate that was handed down from generation to generation. In the past, not only Turks, but also Arabs and Iranians played important roles in trade and Islamic education. Though there is no definite proof about this issue, Turks too, contributed to the Islamization of this region at the beginning." (Azra 1992, 47, 2004, 35).

Emperoum, a village located very close to the center of Banda Aceh, supports this argument because this name apparently stems from its first inhabitants: a group of Ottoman subjects (Lombard 2007, 170). ${ }^{17}$ Empe is an honorific phrase, whereas Rum is used for people coming from Anatolia. In this context, emperoum was used to address the people who lived in this village as an expression of respect and, eventually, it became the name of the village (Cab Sikureueng (Segel Sultan Aceh): Buku Objek Peninggalan Sejarah dan Kepurbakalaan Aceh 1995, 20; Özay 2006, 111).

The Ottoman State's political and cultural power impacted the entire Muslim world including the Islamic sultanates in the Malay Archipelago. In the fifteenth century, Muslims in the Malay world used to call the Ottoman sultan the "King of Rum" (Raja Rum) because of the conquest of Istanbul (Azra 1992, 103; Göksoy 2004, 11). ${ }^{18}$ Besides, this concept is also used for the geographical location beyond Anatolia as seen in the work of Abu'l Fazl. He states that the word Rumistan was used for the Ottoman dependencies of Syria, Palestine, Egypt, and in Northern Africa (Khan 1999, 27).

\section{His Works, Scholarly Personality and Student}

Bāba Dāwud was one of the most important students and successors of al-Sinkilin, who was widely regarded as not only Aceh's but also the Malay world's greatest scholar. The significance of Bāba Dāwud's scholarly personality can be seen from his creation of the Dayah Manyang Leupue, an Islamic education center, together with al-Sinkîli (Hasjmy 1977, 117, 1983, 81). ${ }^{19}$ Bāba Dāwud helped his teacher to complete the Turjumān al-mustafíd which is considered the first Malaylanguage translation and commentary of the Quran (Riddell 2001, 161). ${ }^{20}$ This work, which is considered a significant contribution to the development of Islamic knowledge in the Malay world, was first published in Istanbul in 1884 and has been reprinted from time to time ever since (M. S. Abdullah 1999c, 16; Amiruddin 2005, 13; Johns 
1999, 112; Voorhoeve 1980, 38). ${ }^{21}$ The original copy was given to one of Bāba Dāwud's descendants in southern Thailand and then passed on to Shaykh Ahmad ibn Muhammad Zayn al-Fațānī, who published the first edition of this study.

Although his descendants who still live in Patani and Kelantan say that Bāba Dāwud wrote several books, no concrete confirmation of this has ever been discovered. Bāba Dāwud's manuscript work was copied by Shaykh Dāwud ibn Ismā'îl al-Fațānī, who was the former's descendant, also known as Tok Daud Katib. And Shaykh Ahmad al-Fațānī, Daud Katib's cousin, later took over it. The work was subsequently rewritten by Shaykh Ahmad ibn Muhammad Zayn al-Fațānī, Shaykh Dāwud ibn Ismā'īl al-Faṭānī and Shaykh Idrīs ibn Husayn Kelantanam, all of whom made corrections to the original work. The first copies were published in Istanbul, in Mecca and in Egypt (M. S. Abdullah 1999a, 16; Mokhtar 2008, 54).

There is also an academic paper that said that Bāba Dāwud contributed to the translation of the Mir'at al-tulläb, the work of alSinkīili. Safiyat al-Dīn, the first queen, who ruled Aceh between 16411675, asked 'Abd al-Ra'ūf al-Sinkīili to write a Malay text book. Hence, since al-Sinkīili had spent almost two decades abroad he could no longer write in Pasai Malay, which is known as classical Malay, and he wrote in Arabic instead. After that, the book was translated by two people one of whom was Bāba Dāwud (Daly 1994, 35; Hanafiah 1972, 4).

In addition to contributing to al-Sinkīlīs work, Bāba Dāwud wrote "Risālat masä̀il al-muhtadì li ikhwān al-muhtadī" (The Guide for Right Path for the New Starting Brothers), ${ }^{22}$ a Malay text, which for nearly three hundred years was used as the basic text for instruction in religious schools in Aceh and other parts of the Malay world. ${ }^{23}$ This book is also known as Kitāb masä̀il, particularly in Aceh. ${ }^{24}$ It has been used during the first stage of Islamic education in Aceh, Malaysia, Indonesia, Singapore and Southern Thailand where Malay was spoken (Hasjmy 1983 18).${ }^{25}$ Considering it an important work, Ali Hasjmy asserts that this book has contributed to the religious education of hundreds of thousands of Malay students and is still being used, though partly, in Aceh (Hasjmy 1978, 81). ${ }^{26}$ In addition, Oman Fathurahman states that this work is assumed to have been widely known and studied in the the religious schools and that copies are available in various libraries (Fathurahman 2010, 177). 
This risalah can easily be acquired since it is sold in book stores in Banda Aceh, and in the city of Patani, Thailand as well, as the writer observed on his travels for his research. In addition, during my research I consulted some religious scholars in various regions such as Aceh, Patani and Kelantan about the existence of the Masäill. On the other hand, copies which I have come across in various libraries in Malaysia and Aceh seem to be not the original versions Bāba Dāwud himself wrote but rather the ones various individuals copied throughout time. This is quiet understandable because of the tropical conditions which does not allow paper products to "survive much more than a century" (Jones 2013, xiii).

Written in Malay in the form of a question-answer dialogue, the bestknown method of the time, it imparted elementary religious knowledge to first-year students who did not know Arabic. Interestingly it is still being used today, with no change in content, to teach issues related to faith, worship, and other subjects (Amiruddin 2005, 39; Hasjmy 1983, 382, 1984, 106; Sulaiman 1997, 31). ${ }^{27}$

What makes this book special is that though it is short, it is complete and explains the matter clearly and accurately. One of the salient characteristics of this book is that it managed to reach the common people, particularly the younger generation and newly converted individuals as may be understood from the title. As said elsewhere in this paper, the work was also written in Acehnese and because of its outstanding characteristics some scholars translated it into various other ethnic languages such as Sundanese and Javanese (Hasjmy 1995, 490). There is no doubt that the purpose he wrote the risālah in Acehnese was to forge a link between members of scholarly circles and the common people. The content of the book was designed to convey the fundamental knowledge of Islam needed both for establishing 'aqidah, and for daily ibadah, practical reasons. The question and answer method of the book was also very practical because it was an easy way to convey information to the audience. This is very unique at a time when there were few books for common readers and the available books were intended to serve a relatively higher level of scholarly circles such as specialists, the closed group of religious scholars and their students (Reid 1993, 140). Hence, Masäal al-muhtadi is not one that belongs to this group of works and it was easy for various circles to reproduce it which made that it easily found its way to local communities and outside regions. 
It is well-known that in the history of Aceh, Bandar Aceh, the capital city of Aceh had become an international trade and cultural mart. It may be assumed that this feature made the inhabitants of the city multi-national and multi-religious. In regard to this, the Masäil al-muhtadi might have been a very useful media for non-Muslims to understand the basics of Islam. There is no doubt that Bāba Dāwud was a Muslim proselystists and the book clearly proves his scholarly capacity and his ability to explicate the basics of Islam in the form of a very short book.

However, we do not know whether Bāba Dāwud also produced other works besides the Masäil al-muhtadi. It should not be forgotten that Bāba Dāwud was a disciple of al-Sinkīlì, who was very prolific religious scholar, and collaborating with him in the establishment of the Dayah Manyang. If all these elements are considered, Bāba Dāwud might very well have produced other works he either wrote himself or as al-Sinkillì's co-writer. In addition, it is also commonly known that in the past, religious scholars did not put their names in the books they wrote as they saw this as a sort of arrogance (Hanafiah 2000, 152; Salleh 1978, 5). I might just assume here that at least the work entitled Bidāyat al-mubtadi, which can be found as attached to the Masäali almuhtadi in various libraries in Indonesia and Malaysia may be the work of Bāba Dāwud (Fathurahman 2010, 130). ${ }^{28}$

Many famous scholars studied under Bāba Dāwud, among them Nayan al-Baghdādī, the son of al-Fayrūz al-Baghdādī, the founder of Dayah Tanoh Abee, ${ }^{29}$ and Muhammad Zayn (M. S. Abdullah 1999d, 2; Hermaliza 2007, 7). Al- Baghdādī continued his education in Dayah Leupue di Penaoyung under the supervision of Shaykh Dāwud ibn Ismā'îl ibn Musțafá Rūmī. When al-Baghdādī earned his certificate, Bāba Dāwud encouraged him to open an Islamic educational center in Seulimum, Aceh Besar, 40 km. outside Banda Aceh (Hasjmy 1995, 490, 1997, 4). Thus, Bāba Dāwud is credited with having been the force behind opening Islamic educational institutions there. Shaykh Faqih Celaleddin, from Aceh, was also among the scholars who studied with Bāba Dāwud (M. S. Abdullah 1999b, 41).

\section{Tomb of Bāba Dāwud and His Offspring}

I got my first information about Bāba Dāwud from Imran Nyak Musa, a local resident of Montasik, while conducting fieldwork in Aceh 
in September-December 2005. His tomb is located in a small cemetery near the Leupue Mosque, Gampung Mulia, near Peunayoung. ${ }^{30}$ After the enormous damage caused by the 2004 tsunami, local residents surrounded his tomb with pieces of wood and wire and marked it with the note: Makam Ulama Atjeh. Anak Murid Tg. Syiah Kuala.

During my 2005 visit, intense construction activities were being executed by foreign NGOs and a carpenter's workshop had been set up next to the cemetery. Thanks to the local residents, who had not forgotten the past, the location of Bāba Dāwud's tomb was identified.

Today, there are no living descendants of Bāba Dāwud in Aceh. In southern Thailand, however, the famous scholar Shaykh Dāwud ibn Ismā'îl al-Cavi al-Fațāni lived in Patani and has been put forward as one of his grandsons. Another descendant, Haji Nik Wan Fatma (Kak Mah) binti Haci Wan Abdulkadir Kelantan ibn Shaykh Dāwud ibn Ismā'îl al-Fațānī died on 26 July 1999, in Kota Baru (M. S. Abdullah 1999a, 26-27). ${ }^{31}$

\section{Conclusion}

For a long time, scholars have tried to determine why Islam became so popular in the Malay Archipelago, and also the region's inhabitants have expressed interest in the findings of their research. What kind of phases did Islamization pass though until it became firmly established? Various studies indicate that the indigenous people's adoption of Islam occurred over a long period of time, beginning in the eighth century and continuing up to our own time. Islam was introduced by merchants and Sufis who moved and sometimes resided among the local people. Efforts made by indigenous scholars also helped this transformation. The development of Islam as a result of individual communication demonstrates its slow, but steady penetration.

Aceh, the "Doorway to Mecca" (Azra 2004, 84; Hall 1976, 42, 219; Lapidus 1995,95$),{ }^{32}$ played the primary role in this process. During the first period of Islamic history, its rulers invited scholars from various Muslim lands, especially the Middle East and India (Iskandar 1978, 45; Tjandrasasmita 1988, 71; Yusuf $1980,5-6$ ) as a result of which indigenous religious training centers and scholars emerged. Scholars played important roles in the palace, in educational institutions, and in society. With the start of Islamic missionary activities (da'wah), the number of Islamic educational institutions increased in the region 
and indigenous scholars produced works on various topics. Thus, this corner of the Muslim world created its own civilization and established Islam on solid grounds.

Scholars who came to Aceh, either on their own or on invitation from by the rulers deeply planted the roots of their Islamic teaching by establishing Islamic educational institutions. Although many scholars either came to Aceh or were born and raised there, very little is known about them today. Bāba Dāwud, who was of Turkish descent, shares a similar fate. As we known that religious scholars were very active in Aceh social life particularly until the nineteenth century, (Hasjmy 1984 , 101) it may be assumed that Bāba Dāwud was one of the last members of this generation.

As argued above, Bāba Dāwud lived in an era with a very fruitful literary environment which contemporary scholars accepted as the classical period (Johns 1999, 109). In regard to this, there is no doubt that, the Masäil al-mubtadi in particular deserves to be accepted as part of the literary heritage of Islamic works from the 17th century. And considering that these literary works were vehicles for Malay Islamic enlightenment, there is also no doubt that Bāba Dāwud's work(s)' is/ are salient putative contribution(s), if remembered that he used Malay and Acehnese which definitely enabled a large sector of society both in Aceh and in the greater part of the Malay world, to study his work in the ensuing decades and even centuries.

Besides that, the prominent political leader and scholar in the twentieth century, Ali Hasjmy, argued that the use of Bahasa MelayuJawi was inevitable and played a crucial role in the expansion and improvement of Islamic culture and civilization. In regard to this, particularly the Masäil al-muhtadi and other possible works of Bāba Dāwud can also be assumed as crucial contributions to this intellectual environment (Hasjmy 1984, 106; Ismail 1995, 724).

The Masäil al-muhtadi can be regarded as one of the works that contributed to the improvement of Malay Islamic culture and civilization on the course of time. It may be of interest to add, as some researchers have highlighted and proved, that several Malay manuscripts and scholarly works were in use in Muslim communities in Sri Lanka. In regard to this, copies of the Masäil al-mubtadi may have been moved to Sri Lanka and used as course materials in the classical Islamic education institutions like those found in Aceh and in the Malay Peninsula. As 
mentioned, there were some "small Malay schools intended to import rudimentary instructions in Malay and Tamil functioned during the 19th century" (Hussainmiya 1989, 13). ${ }^{33}$

After all, the only reason Bāba Dāwud is mentioned at all in various books is because he was a student of Syiah Kuala. Based on these data and the role of scholars in Aceh, this study provides some general information about Bāba Dāwud. Due to the lack of well-organized works about him, more comprehensive and deeper studies on this scholar and his works need to be undertaken. 


\section{Endnotes}

1. This work was ordered by the sultanah, Sri Sultan Tàj al-Ālam Șafiyat al-Din and was translated from Arabic into Malay (Alfian 2004, 14; Voorhoeve 1980, 36-37). This work was printed after edited by Shaykh Dāwud al-Fațānī at 'Umm al-Qura Mekkah' in 1884 (H. 1309) (Ismail 1995, 730). Since it is known that 'Abd al-Ra'uf al-Sinkîlī could not write scholarly works in Malay due to his long sojourn abroad, it is probable that some of his students, including Bāba Dāwud, might have given him a hand.

2. Regarding the accessibility to Bāba Dāwud's biography, we faced the same difficulty as with Hamzah Fansuri (Braginsky 1999, 136) and the best way was to reconstruct certain parts of his biography based on available data.

3. For example, a descendant of an Arab in Jambi may be named "Sayyid Shaykh ibn alMarhūm Sayyid al-Sharīf Abū Bahr al-Jāwī” (See Fang 1976, 19).

4. I got this information for the first time on October 4, 2005 and I visited his grave in Kampung Mulia, next to Peunayong, Banda Aceh. Bāba Dāwud's grave is referred to as Makam Teungku di Leupu (Hasjmy 1977, 117; Ibrahim 1977, 17).

5. Bāba Dāwud is also considered one of Syiah Kuala's few khaliffahs (See Kraus 1995, 30 [f.n.11]). And, as Kraus argues in his discussion of Shaykh 'Abd al-Muhyī, who was another of Syiah Kuala's students, the latter was not liberal in appointing khalifahs. In regard to this, it is assumed that Bāba Dāwud must have spent many years with Syiah Kuala (Kraus 1995, 24). In addition, it should be emphasized that 'dayah', a word transformed from 'zawiyah', historically existed in Aceh as general religious education centers (Voorhoeve 1980, 38; Yakub 1980, 322).

6. This work is the first Quranic exegesis in Malay written in Arabic script (Jawi). It measures $22 \times 31 \mathrm{~cm}$. and has 540 pages (Johns 1999, 111; Pameran Literatur Islam 1994, sec. Panitia Festival Baiturrahman Ke-2). This work was written during the time of Sultanah Tāj al-Ālam Șafiyat al-Dīn (Braginsky 2004, 355-56; Hasjmy 1977, 115).

7. The exact title of Abdullah bin Omar bin Muhammed Shirazi al-Baydawi's work is Tafīir anwār al-tanzìl wa asrär ta'wïl. Some researchers argue that this work is a translation of Taefsir Bayzawi (Hasjmy 1977, 115; Voorhoeve 1980, 38; Yunus 2008, 190-91). On the other hand, Anthony Johns asserts that this Quranic exegesis is based on two 'jalälayn, one Jalāl al-Dīn al-Mahallī (d. 1459), and the other Jalāl al-Dīn al-Suyūṭī (d. 1505) (Johns 1999, 111 [f.n.]).

8. The name Bāba Dāwud is mentioned on page of 683 of a manuscript of the Turjumān al-mustafid, See MSS 3316, Pusat Manuskrip Melayu, Perpustakaan Negeri Malaysia, Kuala Lumpur. And 'Abd al-Ra'ūf al-Sinkīili mentions Bāba Dāwud's name as Ali alRūmī who contributed to the writing of the Quranic exegesis (M. S. Abdullah 1991, 160; Daly 1994, 30; Hamka 1980, 4). This book was also published in two volumes in Constantinople in H. 1302 (Voorhoeve 1980, 38).

9. Jalāl al-Dīn was a disciple of Bāba Dāwud (M. S. Abdullah 1999b, 41).

10. Regarding the authority of Wan Mohd. Shaghir Abdullah, I would say that Werner Kraus refers to him as a resource person (Kraus 1990, 706).

11. Leupue is a name given to the mosque on the road from Peunayong to the Lampulo fish market. Hence this name is also remembered at least by some quarters as Bāba Dāwud's epithet. Peter Riddell mentions that Bāba Dāwud's guru, Abdurrauf as-Singkili was living in Peunayong in 1693 (Riddell 1984, 23). In addition, he is also known as Baba Rūmī. And he is remembered as the descendant of a Turkish migrant, who may have arrived in Aceh during the reign of the third sultan, Al-Kahhar (1537-1570) and who settled somewhere in Banda Aceh. What makes him significant in the history of Aceh is no doubt his being a prominent student of Shaykh 'Abd al-Ra' üf al-Sinkīlī. It is believed 
that he contributed to some of Syiah Kuala's writings and collaborated to establish a Dayah near the Aceh River. This is the region which at the time is assumed to have been called Leupue, after which Dayah Manyang Leupue was named. That's why he spent his life there and the reason he was called Tgk. di Leupue. He was buried in the graveyard in the same region. It was fortunately saved by local residents who just wrote "Makam Ulama Atjeh. Anak Murid Tkg. Syiah Kuala" on a plaque after the tsunami of the 26th of December 2004. Today it is possible to pay a visit to his tomb which was rebuilt by the generous contribution of the inhabitants (Z. Ahmad 1971, 55).

12. Mr. Mahmud whom I personally visited in 2005 in Neusu, Banda Aceh, claims to be a descendant of 'Abd al-Ra'ūf al-Sinkilī. Since the beginning of 2005 after the earthquake and the tsunami of 26th December, 2004, he has made efforts to reconstruct al-Sinkili's complex which is located near the sea at the end of Jalan Syiah Kuala. He allowed me to see a photocopy of a hand-written Quran as well.

13. In regard to the term 'Rūmì', there are some explanations in various books which particularly talk about the number of nations operating as soldiers, traders et cetera in the port cities around the Indian Ocean and the Archipelago. For example Diu, a port city in the Western part of India, is called as 'the port of the Turks, the port of Rūmīs because of the large number of foreigners from Anatolia who lived there (Temple 1928, xlvi). In another reference, the concept of 'Rum' covers a larger group of people including Saljuq, Ottoman Turks and the people from Anatolia beyond the earlier usage for the Byzantines, as Orthodox Christians living in Anatolia (Conrad 2005, 237; Hinz 1992, 63).

14. When they were expelled from Baghdad, they had already established other power centers in Anatolia and Anadolu in Asia Minor. Shortly after he had become master of Baghdad, Tughrilbeg dispatched his nephew, Alp Arslan to secure the realm's borders. In 1071, Alp Arslan won one of the most crucial battles in history by defeating the Byzantines and capturing the emperor. Byzantium never recovered and Eastern Anatolia was liberated. As early as 1072, Suleyman, a relative of Alp Arslan, conquered most of Asia Minor. While the First Crusade was reconquering most of Anatolia, Suleyman's son returned to Anatolia and established the state of the Saljuqs of Rum (Gordon 1999, 49-50).

15. It is important to remember that different sources refer to the Turks with different words such as Rum, Rumes, and Turks (Cortesão 1990, 142). Another mentioning of the term 'Rūmì' may be found in the classical text Hikayat Aceh (Iskandar 1978, 175).

16. For similar contexts regarding to 'Rome' See Salleh $(2011,479)$.

17. There is also a relatively early reference to the existence of a Turkish community in Banda Aceh in the beginning of the 17 th century, when Thomas Best visited the area (Foster 1934, 159-60). The silsilah I personally received from a family in Lam Kabeue in Aceh Besar, emphasizes the importance of Kampung "Eumpeue Rom" where some groups of Turkish military personnel, including some Ghazi resided. See "Silsilah Nasab dan Zurriat".

18. There are various other Rum stories in the Malay world. John Bowen refers to one of them he came across when he did his research in Gayo, the central part of Aceh (Bowen 1989, 673).

19. Dayah Manyang is the term to refer to the highest level of classical Islamic education in the region. This term was also used for the education center with various departments that was established in the Masjid Baiturrahman in the 17th century (Hamzah 1986, 3). As we known that 'Abd al-Ra'üf al-Sinkilī was the founder of the Shattariyyah Order in the Archipelago, as one of his successors, Bāba Dāwud could be regarded as the representative of this tariqah after his guru had passed away (Archer 1937, 17; Daudy 1997, 73). As stated by Shaghir Abdullah (1999b, 41), Bāba Dāwud transmitted this țarqah tradition to Shaykh Jalāl al-Dīn. 
20. In the course of time, this work was edited by several scholars such as Shaykh Ahmad Fațānī and Shaykh Idrīs Husayn al-Kelantanī (Ismail 1995, 730).

21. Acehnese scholars exerted great influence in other parts of the Archipelago particularly between the $16^{\text {th }}$ and the $19^{\text {th }}$ centuries (M. S. Abdullah 1999c, 11).

22. In Aceh, this risālah is known under its abbreviated title Masāîl (Sulaiman 1997, 31). Manuscripts of the Masäil al-mubtadi li ikhwān al-muhtadi are available in the Pusat Manuskrip Melayu and in various other libraries such as the Aceh Museum Library, No Inv. 07.315/2280; Perpustakaan Negeri Malaysia, in Kuala Lumpur., MSS 3316, MSS 3662. There are five copies of this book in the Dayah Tanoh Abee Library, Selimium, Aceh Besar, Aceh (Fathurahman 2010, 176, 178-79, 286 and MS in Aceh: INMA 131. Jakarta Vt.80. $17 \times 10.5 \mathrm{~cm}$. Ff. $2 \mathrm{v}-12 \mathrm{v} .15 \mathrm{LL}$. of $8.5 \mathrm{~cm}$. There are also poetic renditions of the contents of the Malay Masäil al-muhtadi li ikhwān al-muhtadi is available in the Indonesian National Library (Ronkel 1909, 397) and in Leiden (Ronkel 1909, 57, 1921, 109; Voorhoeve 1994, 234-35 and Cod.Or. 8506c(2) in the. Damsté Collection). At the back of a copy of the Malay Masäil al-mubtadi there is a Nalam rukon seumayang in pencil (Voorhoeve 1994, 241 see also Amsterdam 2454/5). Damsté Collection (Voorhoeve 1994, 242). Teuku Iskandar $(1999,947)$ also refers to Masail this risālah.

23. Since religious-based scholarly works were the mainstream intellectual written works in the pre-modern era, the use of the Malay language should be taken into special consideration. In regard to this, both native scholars and wandering ulama from various regions who came to Aceh produced their works in Malay. These works included literature and treateses on astrology, mathematics, philosophy, law, history, fiqh, and tasawwuf and the Kitäb masäil al-muhtadi is one among them (Hasjmy 1984, 105-6).

24. Literally ' $k i t a \bar{b} b$ ' means 'book' but in Malay usage, it only means 'religious book' (Ngah 1982, viii).

25. See also Ismail $(1995,726)$.

26. If, particularly, the earlier period is taken into consideration, the Masäil al-mubtadi made a significant contribution to the Aceh-Malay religio-cultural tradition. This is supported by Ali Hasjmy who stresses that the Malay-Jawi language was an undeniable aspect of the Islamic culture and civilization in the Archipelago. It has also been argued that Masäal al-muhtadi has been used as a text book throughout the centuries in various geographies of the Malay Archipelago (Hasjmy 1984, 106).

27. John Anderson, during his visit to the east coast of Sumatra, came across several religious books among which he considered the Masäil al-mubtadi as the principal work (Anderson 1971, 291). During my interview with him on 16 August 2015, Nyak Imran Musa said that some decades ago another version was written in Acehnese . In relation to this oral information, it is also interesting to note that Abdussalam at-Tirawi (from Tiro), another of al-Sinkîlìs disciples, also wrote his book entitled 'Tariq al-mustaqìm ilā jannat al-na 'im' in Acehnese in 1806 (H. 1221) (Voorhoeve 1980, 2). Some other works, such as Qawāi id al-Islām, Kitab Delapan, Soal Jawab Akidah, Tarīq al-mustaqìm ilā jannat al-na'im, and Asal Tahqiq, were written in the same questions and answers form as the Masäil al-muhtadi (Fathurahman and Holil 2007, 51-52, 60, 61; Ismuha 1976, 14-15; Voorhoeve 1980, 22, 23). Ilmu Tauhid dan Syahadat, which was written by Shaykh 'Abd al-Jalī al-Ashī uses the same style (Pameran Literatur Islam 1994, sec. Panitia Festival Baiturrahman Ke-2 20). Syamsuddin Sumatrani's Malay work about the Islamic creed entitled Mir'at al-muminīn (1601), and the Kitab Seribu Masalah (Thousand Questions) dealing with religious dogma and Islamic cosmology, one of the most popular Persian works rendered into Malay and Javanese were also written in questions and answers form (Reid 1993, 155). It has been argued that this book was written in Persian by Abū 'Ālī Muhammad al-Bal'amī under the title 'Tabarī'. And later on 'Abdullāh ibn Salīm rewrote 
it under the title Masā $i l$. It was also translated in several other languages such as Arabic, Hindustani, dan Turkish (Sutrisno 1983, 15). In Aceh, books written in Arabic script are called Kitab Jawoe (Sutrisno 1983, 15). In addition, the language used in these works was also called 'Bahasa Jawoe Pasai' referring to the classical Malay language that developed during the time of the Sultanate of Pasai in northern Aceh between the 13th and the 15th centuries (Hasjmy 1984, 103-4; Ismail 1995, 725). The Masäil al-muhtadi is registered in the catalogue of the Dayah Tanoh Abee Library as anonymous. According to this catalogue there are four manuscripts of this book. In addition, as witnessed in other libraries such as the Manuscript Library of Malaysia, the Masäil al-mubtadi is attached to a book entitled Bidāyatuhu mubtadi bi fadlillāh mubtadi or Bidāyat al-mubtadi bi fadlillăh al-muhdi (Fathurahman 2010, 130) and the latter is regarded as anonymous as well (W. Abdullah and al-Fairusy 1980, 7). One of the five copies of the Masā' $i l$ is attached to another work entitled Sharh nazhat al-tulläb fi al-kashf 'an qawä id al-írab (Fathurahman 2010, 178-79, 286). Apparently, both works use Arabic script and are written in Malay, totalling 178 pages, and measuring $27 \times 17 \mathrm{~cm}$ (Pameran Literatur Islam 1994, sec. Panitia Festival Baiturrahman Ke-2 16, 32). In addition, both works are mentioned in the same place in a booklet which was exhibited during an event at the Masjid Baiturrahman in Banda Aceh, some decades ago. It is mentioned that the Masäal al-mubtadi has 24 pages, while the Bidāyatuhu mubtadi counts 152 pages (Pameran Literatur Islam 1994, sec. Panitia Festival Baiturrahman Ke-2 16, 32). Bahasa Jawi was a very functional language and adopted in all the ports cities in the Archipelago throughout history. It may be assumed that by writing it in Jawi, Bāba Dāwud intended to make his book accessible to other parts of the Malay regions (Hasjmy n.d., 501; Yunus 2008, 192).

28. See MSS 3662, MSS 3316, Pusat Manuskrip Melayu, Perpustakaan Negeri Malaysia, Kuala Lumpur; ML 377, ML 502, National Library of Indonesia, Jakarta; Indeks Rol Mikrofilm, Daftar Isi Rol Mikrofilm Proyek, National Library of Indonesia, Jakarta, p. 619; Koleksi Von de Wall, (R-622), Rol 365.03 (Behrend 1998, 327).

29. See for details Özay (2011).

30. In Jule 2015 I observed that the mosque had been given an 'Arabic' name because of a donation from an Arab country. Azra states that Dawud al-Rūmī's grave is near the Aceh River near al-Sinkilï”. See Azra $(2004,86)$.

31. I personally paid a visit to an elder lady during my field work. She ran an orphanage in a district in Kelantan and claimed to be a descendent of Bāba Dāwud. Unfortunately, she could not supply any information about her grand-grandfather. (July, 2011, Kelantan).

32. In his poems, Hamzah Fansuri, the leading Sufi poet, refers to Banda Aceh as a developed and prosperous city (Batilul Makmur, Bandar Makmur) (Hasjmy 1976, 11). The verse is as follow: "Hamzah gharib unggas quddusi/Akan rumahnya Bayt al-Mamuri/Kursinya sekalian kapuri/Min al ashjari di negeri Fansuri” (Drewes and Brakel 1986, 74).

33. It is rather significant that the Malay Masäil al-mubtadi was easily accessible to various ethnic groups in the Archipelago and even up to Sri Lanka and Madagascar despite their relatively far geographical locations (Maier 2004, 8).

\section{Bibliography}

Abdullah, Mohd. Shaghir. 1991. Khazanah Karya Pusaka Asia Tenggara. Kuala Lumpur: Khazanah Fathaniyah. 
Kuala Lumpur: Persatuan Pengkajian Khazanah Klasik Nusantara: Khazanah Fathaniyah.

1999b. Vol. 6 Penyebaran Islam dan Silsilah Ulama Sejagat Dunia Melayu. Kuala Lumpur: Persatuan Pengkajian Khazanah Klasik Nusantara: Khazanah Fathaniyah.

1999c. Vol. 4 Penyebaran Islam dan Silsilah Ulama Sejagat Dunia Melayu. Kuala Lumpur: Persatuan Pengkajian Khazanah Klasik Nusantara: Khazanah Fathaniyah.

1999d. Vol. 7 Penyebaran Islam dan Silsilah Ulama Sejagat Dunia Melayu. Kuala Lumpur: Persatuan Pengkajian Khazanah Klasik Nusantara: Khazanah Fathaniyah.

Abdullah, Wamad, and Tgk. M. Dahlan al-Fairusy. 1980. Katalog Manuskrip Perpustakaan Pesantren Tanoh Abee, Aceh Besar. Banda Aceh: Pusat Dokumentasi dan Informasi Aceh.

Ahmad, Kassim. 1997. Hikayat Hang Tuah. Kuala Lumpur: Yayasan Karyawan dan Dewan Bahasa dan Pustaka.

Ahmad, Zakaria. 1971. "Dua Tokoh Ulama Besar Di Abad XVII." Sinar Darussalam 34.

Al-Attas, Muhammad Naguib. 1969. A General Theory of the Islamization of the Malay-Indonesian Archipelago. Kuala Lumpur: Dewan Bahasa dan Pustaka.

Alfian, T. Ibrahim. 2004. "Budaya Aceh Dalam Perspektif Sejarah.” Presented at the Seminar Budaya Pekan Kebudayaan Aceh IV, Banda Aceh.

Amiruddin, M. Hasbi. 2005. The Response of the Ulama Dayah to the Modernization of Islamic Law in Aceh. Bangi: Penerbit Universiti Kebangsaan Malaysia.

Andaya, Barbara Watson. 1977. "From Rūm to Tokyo: The Search for Anticolonial Allies by the Rulers of Riau, 1899-1914." Indonesia (24): 123-56.

Anderson, John. 1971. Mission to the East Coast of Sumatra in 1823. Kuala Lumpur: Oxford University Press.

Archer, Raymond LeRoy. 1937. Muhammadan Mysticism in Sumatra.

Azra, Azyumardi. 1992. “The Transmission of Islamic Reformism to Indonesia: Networks of Middle Eastern and Malay-Indonesian 'Ulama' in the Seventeenth and Eighteenth Centuries.” Ph.D. Dissertation. Columbia University.

1998. Jaringan Ulama Timur Tengah dan Kepulauan Nusantara Abad XVII dan XVIII: Melacak Akar-Akar Pembaruan Pemikiran Islam di Indonesia. Jakarta: Mizan.

2004. The Origins of Islamic Reformism in Southeast Asia: Networks of MalayIndonesian and Middle Eastern 'Ulamā in the Seventeenth and Eighteenth Centuries. Crows' Nest, NSW: Allen \& Unwin; Honolulu: University of Hawai'i Press. 
Bates, Ülkü Ü. 1994. "Evliya Çelebi's Comments on the Saljuqs of Rum.” In The Art of the Saljūqs in Iran and Anatolia: Proceedings of a Symposium Held in Edinburgh in 1982, ed. Robert Hillenbrand. Costa Mesa: Mazda Publishers, 257-62.

Behrend, T.E. 1998. Katalog Induk Naskah-Naskah Nusantara. Jakarta: Yayasan Obor Indonesia-École Française d'Êxtreme Orient.

Bowen, John R. 1989. "Narrative Form and Political Incorporation: Changing Uses of History in Aceh, Indonesia." Comparative Studies in Society and History, An International Quarterly 31(4): 671-93.

Braginsky, Vladimir I. 1999. "Towards the Biography of Hamzah Fansuri. When Did Hamzah Live? Data From His Poems and Early European Accounts." Archipel (57): 135-75.

- 2004. The Heritage of Traditional Malay Literature: A Historical Survey of Genres, Writings and Literary Views. Leiden: KITLV Press.

Bressan, L. 1997. "Odoric of Pordenone (1265-1331): His Vision of China and South-East Asia and His Contribution to Relations between Asia and Europe." Journal of the Malayan Branch of the Royal Asiatic Society 70(2): 1-23.

Cab Sikureueng (Segel Sultan Aceh): Buku Objek Peninggalan Sejarah dan Kepurbakalaan Aceh. 1995. 2nd Edition. Banda Aceh: Perkumpulan Pencinta Peninggalan Sejarah dan Kepurbakalaan Aceh (P3SKA).

Conrad, Lawrence I. 2005. "Theophanes and the Arabic Historical Tradition: Some Indications of Intercultural Transmission.” In Arab-Byzantine Relations in Early Islamic Times, ed. Michael David Bonner. Surrey: Ashgate-Variorum.

Cortesão, Armando, ed. 1990. The Suma Oriental of Tome Pires, Vol. 1. New Delhi: Asian Educational Services.

Daly, Peunoh. 1994. Hukum Perkahwinan Islam: Suatu Kajian Perbandingan di Kalangan Ablus-Sunnah dan Negara-Negara Islam. 2nd Edition. Selangor: Thinker's Library.

Daudy, Ahmad. 1997. "Kalimah Tauhid Dalam Ajaran Syeikh Abdurrauf Dan Syeikh Nuruddin Ar-Raniry.” Al-Islam.

Drewes, Gerardus Willebrordus Joannes, and L. F Brakel. 1986. The Poems of Hamzah Fansuri. Cinnaminson: Foris Publications.

Fang, Liaw Yock. 1976. Undang-Undang Melaka (the Laws of Melaka). The Hague: Martinus Nijhoff.

Fathurahman, Oman. 2010. Katalog Naskah Dayah Tanoh Abee, Aceh Besar. Jakarta; Tokyo: Komunitas Bambu; Tokyo University of Foreign Studies (TUFS).

Fathurahman, Oman, and Munawar Holil. 2007. Katalog Naskah Ali Hasjmy 
Aceh (Catalogue of Aceh Manuscripts: Ali Hasjmy's Collection). Tokyo: Centre for Documentation and Area-Transcultural Studies.

Flemming, Barbara. 1988. "Political Genealogies in the Sixteenth Century." In Osmanlı Araştırmaları, Istanbul: Enderun Kitabevi.

Foster, Sir William. 1934. The Voyage of Thomas Best to the East Indies, 1612-14. London: The Hakluyt Society.

Göksoy, İsmail Hakk1. 2004. Güneydoğu Asya'da Osmanl-Türk tesirleri. Isparta: Fakülte Kitabevi.

Gordon, Alijah, ed. 1999. "The Milieu of Syed Shaykh's Formative Years And The Aspirations of the Subjugated Umma." In The Real Cry of Syed Shaykh Al-Hady: With Selections of His Writings by His Son Syed Alwi Al-Hady, Kuala Lumpur: Malaysian Sociological Research Institute.

Hall, Daniel George Edward. 1976. A History of South East Asia. London: Macmillan Press Ltd.

Hamka. 1980. "Sebab Aceh Serambi Mekkah.” Presented at the Seminar Sejarah Masuk dan Berkembangnya Islam di Aceh dan Nusantara, Majelis Ulama Propinsi Daerah Istimewa Aceh dan Pemerintah Daerah Tk. II Aceh Timur.

Hamzah, Soufyan. 1986. "Kristalisasi Pola Fikir Rakyat Aceh.” Presented at the Seminar Ilmu Pengetahuan dan Kebudayaan, Wisata Takengon, Majlis Ulama Indonesia Propinsi Daerah Istimewa Aceh Bekerjasama Dengan Pemerintah Daerah Tk. II. Aceh Tengah/MUI.

Hanafiah, Adnan. 1972. "Peranan Sastra Atjeh Dalam Sastra Indonesia.” Presented at the Seminar Kebudajaan dalam Rangka Pekan Kebudajaan Atjeh Ke-II, Banda Aceh.

—. 2000. "Semangat Kepahlawanan dalam Karya Sastera Aceh." In Globalisme dan Patriotisme dalam Sastera Melayu: Kumpulan Kertas Kerja Hari Sastera 1995, eds. Abdul Latiff Abu Bakar and Othman Puteh. Kuala Lumpur: Dewan Bahasa dan Sastera, 148-59.

Hasjmy, Ali. 1976. Ruba’i Hamzah Fansuri: Karya Sastra Sufi Abad XVII. Kuala Lumpur: Dewan Bahasa dan Pustaka.

1977. 59 Tahun Aceh Merdeka di bawah Pemerintahan Ratu. Jakarta: Bulan Bintang.

- 1978. Bunga Rampai Revolusi dari Tanah Aceh. Jakarta: Bulan Bintang.

-1983. Kebudayaan Aceh Dalam Sejarah. Jakarta: Beuna.

—. 1984. "Peranan Huruf Arab Melayu "Tulisan Jawi' Dalam Usaha Menjadikan Bangsa-Bangsa Di Nusantara Cerdas Dan Bertamaddun.” Sinar Darussalam (139): 100-111.

1995. "Hamzah Fansury: Sastrawan Sufi Nusantara Terbesar." In 
Seulawah: Antologi Sastra Aceh Sekilas Pintas, eds. L.K. Ara, Taufik Ismail, and Hasyim K.S. Jakarta: Yayasan Nusantara, 487-502.

- 1997. Ulama Aceh: Mujahid, Pejuang Kemerdekaan, dan Pembangun Tamadun Bangsa. Jakarta: Bulan Bintang.

_. "Menyimpan Alam Pikiran Melayu Lama." Sinar Darussalam.

Hermaliza, Essi. 2007. Tgk. Abu Dahlan al-Fairussy al-Baghdady: Pewaris Manuskrip Kuno dan Zawiyah Tanoh Abee. Banda Aceh: Balai Pelestarian Sejarah dan Nilai Tradisional.

Hinz, Walther. 1992. Uzun Hasan ve Şeyh Cüneyd: XV: Yüzyılda İan’ın Millî Bir Devlet Haline Yükselişi. Ankara: Türk Tarih Kurumu Basımevi.

Hurgronje, C. Snouck. 1906. I-II The Acehnese. Leiden: E.J. Brill.

Hussainmiya, Bachamiya Abdul. 1989. "Baba Ounus Saldin (b.1832-D. 1906): An Account of a Malay Literary Savant or Sri Lanka." In Persidangan Antarabangsa Tamadun Melayu Ke II, 15-20 August 1989, Kuala Lumpur, Malaysia: Kementerian Kebudayaan dan Pelancongan; Dewan Bahasa dan Pustaka, 1-69.

Ibrahim, Husaini. 1977. "Makam Sebagai Sumber Sejarah.” Sinar Darussalam (220): 13-20.

Inalc1k, Halil. 19vr. The Ottoman Empire: The Classical Age, 1300-1600. London: Weidenfeld and Nicolson.

Iskandar, Teuku. 1978. Hikayat Aceh: Kisah Kepahlawanan Sultan Iskandar Muda. Banda Aceh: Proyek Rehabilitasi dan Perluasan Museum Daerah Istimewa Aceh.

- 1999. 2 Catalogue of Malay, Minangkabau, and South Sumatran Manuscripts in the Netherlands. Leiden: Documentatiebureau IslamChristendom.

Ismail, Mat Rofa. 1995. "Bahasa Melayu Bahasa Ilmiah: Penulisan Teks Klasik Ilmu Tauhid dalam Bahasa Melayu." Jurnal Dewan Bahasa: 723-41.

Ismuha. 1971. "Tengku Abd. Rahman Meunasah Meutjap: Pemimpin Pendidik Dan Pendiri Persatuan Ulama Seluruh Atjeh (PUSA).” Sinar Darussalam (33). 1976. Ulama Aceh Dalam Perspektif Sejarah. Jakarta: Lembaga Ekonomi dan Kemasyarakatan Nasional Lembaga, Ilmu Pengetahuan Indonesia (LEKNAS-LIPI).

Johns, A. H. 1976. "Islam in Southeast Asia: Problems of Perspective." In Southeast Asian History and Historiography: Essays Presented to D. G. E. Hall, eds. C. D Cowan and O. W Wolters. Ithaca: Cornell University Press.

1999. “'She Desired Him and He Desired Her' (Qur'an 12:24): 'Abd alRa'uff's Treatment of an Episode of the Joseph Story in Tarjumân al-Mustafîd.” Archipel 57(2): 109-34. 
Jones, Russell. 2013. "Introduction." In The Pasai Chronicle, Kuala Lumpur: Institut Terjemahan \& Buku Malaysia, xii-xxxii.

Khan, Iqtidar Alam. 1999. "Nature of Gunpowder Artillery in India during the Sixteenth Century: A Reappraisal of the Impact of European Gunnery." Journal of the Royal Asiatic Society 9(1): 27-34.

Kraus, Werner. 1990. "Some Notes on the Introduction of the NaqshabdiyyaKhalidiyya into Indonesia." In Naqshbandis: Cheminements et Situation Actuelle d'un Ordre Mystique Musulman, ed. Marc Gaborieau. Istanbul; Paris: ISIS, 691-706.

1995. "An Enigmatic Saint: Syekh Abdulmuhyi of Pamijahan (?16401715?).” Indonesia Circle 23(65): 21-31.

Laffan, Michael F. 2003. "New Charts for the Arabic Ocean Dictionaries as Indicators of Changing Times." Bijdragen tot de taal-, land-en volkenkunde 159(2/3): 351-87.

Lapidus, Ira M. 1995. A History of Islamic Societies. 7th Edition. Cambridge: Cambridge University Press.

Lombard, Denys. 2007. Kerajaan Aceh Zaman Sultan Iskandar Muda (16071636). Paris; Jakarta: École française d'Extrême-Orient; Kepustakaan Populer Gramedia (KPG).

Maier, Hendrik M. J. 2004. We Are Playing Relatives: A Survey of Malay Writing. Leiden: KITLV Press.

Marong Mahawangsa: The Kedah Annals. 2011. Kuala Lumpur: Silverfish Books.

Mersinli, Cemal. 1941. “Roma-Rum Kelimeleri'” TTK Belleten 5(17-18).

Mokhtar, Ahmad Baha'. 2008. "Syarh Latif' ala Arba'in Hadithan li al-Imam al-Nawawi Karangan Syeikh Abd Rauf al-Fansuri: Satu Kajian Teks.” Ph.D. Dissertation. Al-Quran dan Al-Hadith Akademi Pengajian Islam, Universiti Malaya.

Ngah, Mohamed Nor bin. 1982. Kitab Jawi: Islamic Thought of the Malay Muslim Scholars. Singapore: ISEAS.

Özay, Mehmet. 「 ‥ . Açe Kitabı. İstanbul: Fide Yayınları.

. 2011. "A Preliminary Note on Dayah Tanoh Abee." In Ottoman Connections to the Malay World: Islam, Law and Society, ed. Saim Kayadibi. Kuala Lumpur: Other Press, 56-85.

Pameran Literatur Islam. 1994. Banda Aceh, Propinsi Daerah Istimewa Aceh.

Reid, Anthony. 1993. Southeast Asia in the Age of Commerce, 1450-1680: Expansion and Crisis. Chiang Mai: Silkworm Books.

- 2005. An Indonesian Frontier: Acehnese and Other Histories of Sumatra. 
Singapore: Singapore University Press.

Riddell, Peter G. 1984. "Abd Al-Raūf Al-Singkilīs Tarjumān Al-Mustafīd: A Critical Study of His Treatment of Juz 16." Ph.D. Dissertation. Australian National University.

-2001. Islam and the Malay-Indonesian World: Transmission and Responses. Singapore: Horizon Books.

Rinkes, D. A. 1996. Nine Saints of Java. Kuala Lumpur: Malaysian Sociological Research Institute.

Ronkel, Philippus Samuel van. 1909. Catalogus der Maleische Handschriften in het Museum van het Bataviaasch Genootschap van Kunsten en Wetenschappen. Batavia; 's Hage: Albrecht; Nijhoff.

-1921. Supplement-catalogus der Maleische en Minangkabausche handschriften in de Leidsche universiteits-bibliotheek. Leiden: E.J. Brill.

Salleh, Muhammad Haji. 1978. "From Sejarah Melayu the Prologue.” Presented at the International Symposium on Traditional Malay Literature held by Jabatan Persuratan Melayu, Universiti Kebangsaan Malaysia.

- 2011. The Epic of Hang Tuah. Kuala Lumpur: Institut Terjemahan Negara Malaysia.

Seljuq, Affan. 1980. "Relations between the Ottoman Empire and the Muslim Kingdoms in the Malay-Indonesian Archipelago.” Der Islam 57: 301-10.

Sulaiman, M. Isa. 1997. Sejarah Aceh: Sebuah Gugatan terhadap Tradisi. Jakarta: Pustaka Sinar Harapan.

Sutrisno, Sulastin. 1983. Hikayat Hang Tuah: Analisa Struktur dan Fungsi. Yogyakarta: Gadjah Mada University Press.

Temple, Richard Carnac. 1928. The Itinerary of Ludovico Di Varthema of Bologna: From 1502 to 1508. London: The Argonaut Press.

Tjandrasasmita, Uka. 1988. Aceh Dalam Retrospeksi Dan Refleksi Budaya Nusantara. Jakarta: INTIM (Informasi Taman Iskandar Muda).

Voorhoeve, P. 1980. Bayān Tajallì: Bahan-Bahan untuk Mengadakan Penyelidikan Lebih Mendalam tentang Abdurra-uf Singkel. Banda Aceh: Pusat Dokumentasi dan Informasi Aceh.

-1994. Catalogue of Acehnese Manuscripts in the Library of Leiden University and Other Collections Outside Aceh. Leiden: Leiden University Library (Legatum Warnerianum) in co-operation with Indonesian Linguistics Development Project (ILDEP).

Yakub, Ismail. 1980. "Gambaran Pendidikan di Aceh sesudah Perang AcehBelanda sampai Sekarang." In Bunga Rampai tentang Aceh, ed. Ismail Suny. Jakarta: Bhratara Karya Aksara, 318-72. 
Yunus, Mahmud. 2008. Sejarah Pendidikan Islam di Indonesia. 3rd ed. Jakarta: Mahmud Yunus Wadzurriyyah.

Yusuf, Ilyas. 1980. "Sejarah Masuk Dan Berkembangnya Agama Islam Di Kabupaten Aceh Besar." Presented at the Sejarah Masuk dan Berkembangnya Islam di Aceh dan Nusantara, Majelis Ulama Propinsi Daerah Istimewa Aceh dan Pemerintah Daerah Tingkat II Aceh Timur, in East Aceh.

\section{Manuscript}

Masäil al-mubtadi li ikhwān al-mubtadi

No Inv. 07.315/2280, Aceh Museum Library, Banda Aceh. Indonesia.

MSS 3662, MSS 3316, Pusat Manuskrip Melayu, Perpustakaan Negeri Malaysia, Kuala Lumpur.

ML 377, ML 502, National Library of Indonesia,

Indeks Rol Mikrofilm, Daftar Isi Rol Mikrofilm Proyek, National Library of Indonesia, Jakarta.

\section{Silsilah}

Silsilah Nasab dan Zurriat, Lam Kabeue, Aceh Besar. (Personal visit and interview with the family, 2 August, 2015.

\section{Interviews}

Interview with Imran Nyak Imran Musa, Banda Aceh, September-December 2005.

Interview with Tgk. Mahmud in Neusu, Banda Aceh, September-December, 2005 ,

Interview with Hajjah Wan Hatijah, Kelantan, Malaysia, July, 2011.

Interview with Nyak Imran Musa, Montasik, Aceh Besar, August, 16 ${ }^{\text {th }}, 2015$.

Mehmet Özay, Independent Researcher, Turkey. Email: mehmedozay@ gmail.com. 


\section{Guidelines}

\section{Submission of Articles}

tudia Islamika, published three times a year since 1994, is a bilingual (English and Arabic), peer-reviewed journal, and specializes in Indonesian Islamic studies in particular and Southeast Asian Islamic studies in general. The aim is to provide readers with a better understanding of Indonesia and Southeast Asia's Muslim history and present developments through the publication of articles, research reports, and book reviews.

The journal invites scholars and experts working in all disciplines in the humanities and social sciences pertaining to Islam or Muslim societies. Articles should be original, research-based, unpublished and not under review for possible publication in other journals. All submitted papers are subject to review of the editors, editorial board, and blind reviewers. Submissions that violate our guidelines on formatting or length will be rejected without review.

Articles should be written in American English between approximately 10.000-15.000 words including text, all tables and figures, notes, references, and appendices intended for publication. All submission must include 150 words abstract and 5 keywords. Quotations, passages, and words in local or foreign languages should 
be translated into English. Studia Islamika accepts only electronic submissions. All manuscripts should be sent in Ms. Word to: http:// journal.uinjkt.ac.id/index.php/studia-islamika.

All notes must appear in the text as citations. A citation usually requires only the last name of the author(s), year of publication, and (sometimes) page numbers. For example: (Hefner 2009a, 45; Geertz 1966, 114). Explanatory footnotes may be included but should not be used for simple citations. All works cited must appear in the reference list at the end of the article. In matter of bibliographical style, Studia Islamika follows the American Political Science Association (APSA) manual style, such as below:

1. Hefner, Robert. 2009a. "Introduction: The Political Cultures of Islamic Education in Southeast Asia," in Making Modern Muslims: The Politics of Islamic Education in Southeast Asia, ed. Robert Hefner, Honolulu: University of Hawai'i Press.

2. Booth, Anne. 1988. "Living Standards and the Distribution of Income in Colonial Indonesia: A Review of the Evidence." Journal of Southeast Asian Studies 19(2): 310-34.

3. Feener, Michael R., and Mark E. Cammack, eds. 2007. Islamic Law in Contemporary Indonesia: Ideas and Institutions. Cambridge: Islamic Legal Studies Program.

4. Wahid, Din. 2014. Nurturing Salafi Manhaj: A Study of Salafi Pesantrens in Contemporary Indonesia. PhD dissertation. Utrecht University.

5. Utriza, Ayang. 2008. "Mencari Model Kerukunan Antaragama." Kompas. March 19: 59.

6. Ms. Undhang-Undhang Banten, L.Or.5598, Leiden University.

7. Interview with K.H. Sahal Mahfudz, Kajen, Pati, June $11^{\text {th }}$, 2007.

Arabic romanization should be written as follows:

Letters: ', $b, t, t h, j, h, k h, d, d h, r, z, s, s h, s, d, t, z, ', g h, f, q, l$, $m, n, h, w, y$. Short vowels: $a, i, u$. long vowels: $\overline{\mathrm{a}}, \overline{\mathrm{i}}, \overline{\mathrm{u}}$. Diphthongs: $a w$, ay. Tà marbūtāa: t. Article: al-. For detail information on Arabic Romanization, please refer the transliteration system of the Library of Congress (LC) Guidelines. 
ستوديا إسلاميكا (ISSN 0215-0492; E-ISSN: 2355-6145) بحلة علمية دولية محكمة تصدر عن مركز دراسات الإسلام والمجتمع (PPIM) بجامعة شريف هداية الله الإسلامية الحكومية بجاكرتا، تعنى بدراسة الإسلام في إندونيسيا خاصة وفي جنوب شرقي آسيا عامة. وتستهدف المجلة نشر البحوث العلمية الأصيلة والقضايا المعاصرة حول الموضوع، كما ترحب بإسهامات الباحثين أصحاب التخصصات ذات الصلة. وتخضع جميع الأبحاث المقدمة للمجلة للتحكيم من قبل لجنة مختصة. تم اعتماد ستوديا إسلاميكا من قبل وزارة التعليم و الثقافة بجمهورية إندونيسيا باعتبارها دورية علمية (قرار المدير العام للتعليم العالي رقم: 56/DIKTI/Kep/2012).

ستوديا إسلاميكا عضو في CrossRef (الإحالات الثابتة في الأدبيات الأكاديمية) منذ ع ا • ب، و بالتالي سإن جميع المقالات التي نشرها مرقمة حسب معرّف الوثيقة الرقمية (DOI) .

حقوق الطبعة محفوظة عنو ان المر اسلة:

Editorial Office: STUDIA ISLAMIKA, Gedung Pusat Pengkajian Islam dan Masyarakat (PPIM) UIN Jakarta, Jl. Kertamukti No. 5, Pisangan Barat, Cirendeu, Ciputat 15419, Jakarta, Indonesia. Phone: (62-21) 7423543, 7499272, Fax: (62-21) 7408633; E-mail: studia.islamika@uinjkt.ac.id Website: http://journal.uinjkt.ac.id/index.php/studia-islamika

$$
\begin{aligned}
& \text { قيمة الاشتر الك السنوي خارج إندونيسيا: }
\end{aligned}
$$

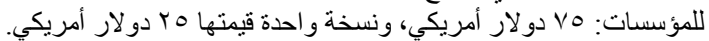

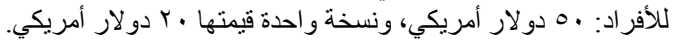

$$
\begin{aligned}
& \text { والقيمة لا تشمل نفقة الإرسال بالبريد الجوي، ونسي. }
\end{aligned}
$$

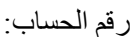

$$
\begin{aligned}
& \text { خارج إندونيسيا (دولار أمريكي): }
\end{aligned}
$$

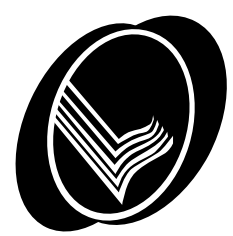




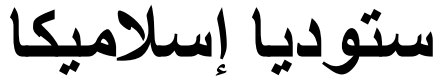 \\ مجلة إندونيسيا للار اسات الإسلامية

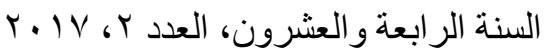

$$
\begin{aligned}
& \text { أزيوماردي أزرا } \\
& \text { مدير التحرير: الرمان }
\end{aligned}
$$

هيئة التحريز: - مئ

سيف المزاني

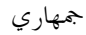

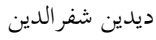

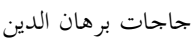

فؤاد جبلي برات لمان

علي منحنف

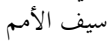

عصمة الرفيع

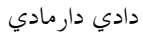

جاجانج جهراني

دين واحد

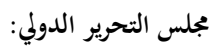

كمدم قريش شهاب (جامعة شريف هداية الله الإسلامية الحكومية بحاكر تا) توفيق عبد الله (المركز الإندو نيسي للعلوم) نور أ. فاضل لو بيس (الجامعة الإسلامية الحكومية سومطرة الشمالية) م.ش. ش. ريكليف (جامعة أستراليا الحكومية كانبيرا) مارتين فان برونيسين (جامعة أتريخة)

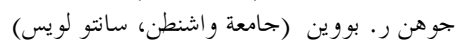
محمد كمال حسن (الجامعة الإسلامية العالمية - ماليزيا)

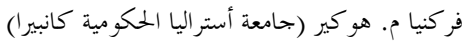
إيدو ين ف. ويربنا (جامعة كولونيا، ألمانيا)

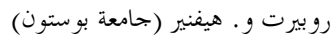
ريكي مادينير (المركز القومي للبحث العلمي بفرنسا)

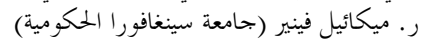
ميكائيل ف. لفان (جامعة فريشتون)

مساعد هيئة التحرير:

$$
\text { تيستريونو التحري }
$$

محمد نداء فضلان إندي أولياء غراديان

مراجعة اللغة الإنجليزية:

ديك فان دير ميج الانيزية

دانيل فترسون فان دير مين

مراجعة اللغة العربية: توباغوس أدي أسناوي

$$
\text { تصميم الغلاف: برنكا }
$$





\section{لالتوايا السالمسيا}




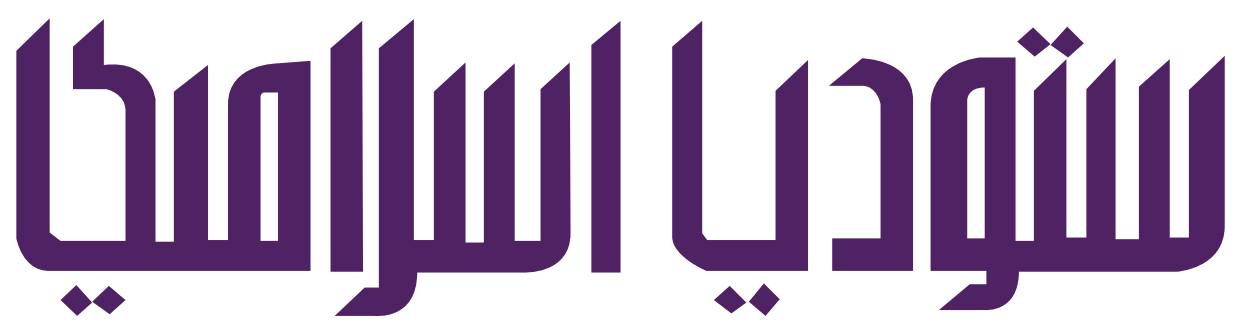

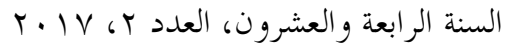

بحلة إنلدونيسية للدراسات الإسلامية

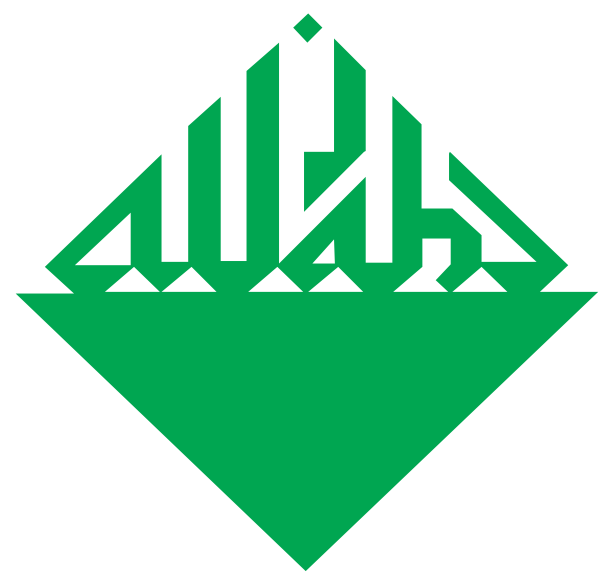

الحركائ المناهضة للمشايغ

والعلماء الحمر هنيى Priangan:

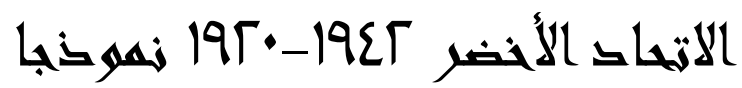

محمد إسكندر 